\title{
OPTIMASI UKURAN TERAS DAN DAYA TERMAL TERHADAP TINGKAT SIRKULASI ALAMIAH BAHAN PENDINGIN Pb-Bi PADA REAKTOR CEPAT
}

\author{
Sri Oktamuliani dan Dian Fitriyani \\ Jurusan Fisika Universitas Andalas \\ Kampus Limau Manis UNAND Padang \\ srioktamuliani@ymail.com \\ difiaal@gmail.com
}

\begin{abstract}
ABSTRAK
Telah dilakukan analisis pengaruh ukuran teras geometri kubus terhadap tingkat sirkulasi alamiah bahan pendingin $\mathrm{Pb}-\mathrm{Bi}$ pada reaktor cepat LMFBR dengan bahan bakar UN-PuN dan laju aliran massa pendingin total $4000 \mathrm{~kg} / \mathrm{s}$ menggunakan program simulasi komputasi DTRIDI. Simulasi diawali oleh perhitungan neutronik yang memberikan hasil harga multiplikasi neutron dan fluks neutron yang dapat digunakan untuk perhitungan termal-hidrolik sehingga diketahui distribusi temperatur pada elemen bahan bakar dan pendingin. Tingkat sirkulasi alamiah dilakukan dengan pendekatan kuasistatik dari grafik yang ditunjukkan oleh perpotongan antara presure drop dan driving head sebagai fungsi dari laju alir total pendingin. Pada kondisi tersebut, adanya pengurangan daya pompa yang digunakan. Tingkat sirkulasi alamiah berdasarkan optimasi ukuran teras dan daya termal tercapai pada ukuran geometri teras yang lebih kecil dengan daya yang lebih besar. Tingkat sirkulasi alamiah pada daya $150 \mathrm{MWth}$ tercapai pada ukuran geometri teras yang lebih kecil yaitu $50 \mathrm{~cm}$ bervolume 125 liter sebesar 12,5\%. Sedangkan untuk reaktor dengan ukuran teras $80 \mathrm{~cm}$ tidak menunjukkan tingkat sirkulasi alamiah yang berarti reaktor dalam keadaan bahaya jika terjadi kecelakaan ULOF yaitu kecelakaan akibat hilangnya daya pompa.
\end{abstract}

Kata Kunci: $\quad$ sirkulasi alamiah, LMFBR, distribusi temperatur, pressure drop, faktor multiplikasi neutron, ULOF

\section{PENDAHULUAN}

Reaktor nuklir adalah tempat terjadinya reaksi inti berantai terkendali, baik pembelahan inti (fisi) atau penggabungan inti (fusi). Reaktor fisi berdasarkan perbedaan spektrum energi neutronnya dapat dibedakan atas reaktor cepat dan reaktor termal. Reaktor cepat merupakan salah satu kandidat reaktor generasi IV yang tengah dikembangkan saat ini. Salah satu keunggulannya adalah dapat mengkonversi bahan fertil yang berlimpah di alam (seperti ${ }^{238} \mathrm{U}$ ) menjadi bahan fisil (seperti ${ }^{239} \mathrm{Pu}$ ) dengan memanfaatkan neutron berenergi tinggi (Waltar dan Reynolds, 1981).

Reaktor diharapkan dapat dioperasikan dengan sistem keselamatan inheren (inherent safety) yaitu reaktor mampu bertahan secara mandiri tanpa mengalami pemadaman otomatis atau bantuan dari operator pada saat terjadi kecelakaan (kondisi abnormalitas). Adapun salah satu kecelakaan yang mungkin terjadi diantaranya adalah ULOF (Unprotected loss of flow) yang merupakan kecelakaan akibat hilangnya daya pompa tanpa proteksi. Pada kecelakaan ULOF terjadi ketidakseimbangan daya dan aliran pendingin yang menyebabkan kenaikan temperatur pendingin dan bahan bakar, kondisi ini akan berbahaya jika batasan-batasan termal pada bahan struktur terlampaui. Tetapi kenaikan temperatur ini menyebabkan terjadinya reaktivitas Balikan negatif yang kemudian menekan daya untuk turun dan akhirnya menyesuaikan dengan kemampuan sirkulasi alamiah. 
Sirkulasi alamiah merupakan proses perpindahan panas akibat adanya perbedaan temperatur pada pipa sehingga aliran fluida pendingin timbul karena daya apung fluida pendingin tersebut. Bahasan termal-hidrolik reaktor yaitu proses konduksi dan konveksi panas serta proses aliran pendingin keluar dari teras maupun pada pembangkit uap (Gambar 1) sangat penting untuk dianalisis sehingga reaktor dapat berada pada kondisi tingkat sirkulasi alamiah yang mendukung tercapainya keselamatan inheren pada reaktor ketika terjadi kecelakaan karena hilangnya daya pompa utama pada reaktor nuklir.

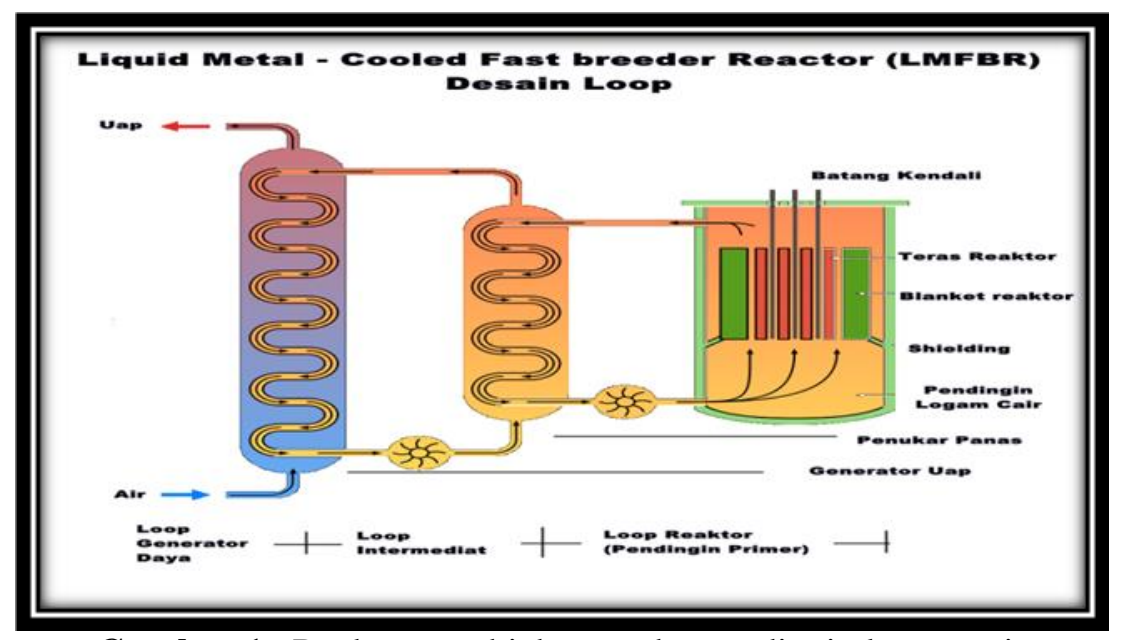

Gambar 1. Reaktor pembiak cepat berpendingin logam cair

Perhitungan analisis keselamatan reaktor nuklir dengan pendekatan probabilistik ataupun deterministik sangat sulit dilakukan secara analitik. Untuk itu diperlukan perhitungan secara numerik melalui simulasi komputasi sehingga diperoleh kemudahan untuk suatu tahapan perhitungan yang tidak sederhana.

Penelitian melalui simulasi komputasi ini bertujuan menganalisis pengaruh ukuran teras terhadap tingkat sirkulasi alamiah bahan pendingin $\mathrm{Pb}-\mathrm{Bi}$ pada reaktor cepat LMFBR (Liquid Metal-Cooled Fast Breeder Reactor) saat terjadinya kecelakaan akibat hilangnya daya pompa. Bahan bakar yang diguanakan adalah campuran Uranium-Nitrida dan Plutonium-Nitrida (UN-PuN). Sistem perpindahan panas digunakan model lup (loop) tanpa penukar panas menengah (Intermediate Heat Exchanger, IHX).

\section{METODE}

Simulasi komputasi untuk mengetahui fenomena tingkat sirkulasi alamiah reaktor pembiak cepat berpendingin logam cair, dilakukan pada desain reaktor dengan spesifikasi reaktor seperti terlihat pada Tabel 1.

Pada model teras reaktor dilakukan diskritisasi ruang untuk memperoleh pendekatan dan penyesuaian terhadap model teoritik. Geometri teras berbentuk kubus dibagi dalam beberapa daerah dengan variasi lebar dan setiap daerah dibagi lagi menjadi beberapa mesh. Seluruh perhitungan dilakukan untuk setiap mesh. Pembagian teras diperlukan untuk mempermudah pengaturan komposisi dan fraksi bahan bakar, pengayaan maupun bahan pendingin di teras sehingga optimasi disain untuk memperoleh nilai penurunan tekanan pada setiap laju aliran pendingin menjadi lebih cepat tercapai. 
Tabel 1. Spesifikasi desain LMFBR

\begin{tabular}{|l|l|l|}
\hline \multicolumn{1}{|c|}{ Parameter } & Spesifikasi \\
\hline Daya Reaktor & $150 \mathrm{MWth}$ \\
\hline Pendingin & $\mathrm{Pb}-\mathrm{Bi}$ \\
\hline Bahan Shielding & $\mathrm{B}_{4} \mathrm{C}+$ Stainless steel \\
\hline Bahan Bakar & $\mathrm{UN}-\mathrm{PuN}$ \\
\hline Pengayaan Bahan Pendingin & $44,5 \% \mathrm{~Pb}-55,5 \% \mathrm{Bi}$ \\
\hline \multirow{4}{*}{ Teras } & Diameter pin bahan bakar & $1,0 \mathrm{~cm}$ \\
\cline { 2 - 3 } & Tebal cladding & $0,05 \mathrm{~cm}$ \\
\cline { 2 - 3 } & Pin picth bahan bakar & $1,2 \mathrm{~cm}$ \\
\hline \multirow{5}{*}{ Generator Uap } & Tinggi SG & $4 \mathrm{~m}$ \\
\cline { 2 - 3 } & Diameter pipa (inner/outer) & $1,7 / 2,0 \mathrm{~cm}$ \\
\cline { 2 - 3 } & Pitch pipa & $3 \mathrm{~cm}$ \\
\cline { 2 - 3 } & Laju alir primer & $4000 \mathrm{~kg} / \mathrm{s}$ \\
\cline { 2 - 3 } & Laju alir skunder & $100 \mathrm{~kg} / \mathrm{s}$ \\
\cline { 2 - 3 } & Temperatur air & $225{ }^{\circ} \mathrm{C}$ \\
\hline
\end{tabular}

Pembahasan neutronik di dalam reaktor dilakukan melalui persamaan difusi neutron. Solusi persamaan difusi memberikan bentuk distribusi fluks neutron dalam ruang, harga multiplikasi $\left(\mathrm{K}_{\mathrm{eff}}\right)$ dan selanjutnya diperoleh distribusi daya dalam elemen bahan bakar, sehingga melalui analisis termal-hidrolik distribusi temperatur dalam elemen bahan bakar dapat diketahui dengan pasti. Temperatur pada pusat elemen bahan bakar merupakan titik awal untuk melakukan analisis termal-hidrolik untuk mengetahui suhu pada permukaan bahan bakar, permukaan bagian dalam maupun bagian luar cladding, dan untuk selanjutnya mengetahui distribusi temperatur dan tekanan pada pendingin. Dengan demikian fenomena tingkat sirkulasi alamiah pada reactor dapat dianalisis.

Timbal-bismuth cair merupakan kandidat yang sangat kuat untuk menjadi pendingin reaktor pembiak cepat. Sifat yang menguntungkan $\mathrm{Pb}-\mathrm{Bi}$ cair dalam aplikasi pendingin reaktor nuklir adalah titik lelehnya $125^{\circ} \mathrm{C}$ dan titik didihnya $1670{ }^{\circ} \mathrm{C}$ dengan perubahan volume ketika berubah menjadi padat sebesar $1,5 \%$. Kelemahannya, sangat agresif terhadap besi dan stainless steel terutama pada temperatur tinggi. Oleh karena itu dalam reaktor nuklir berpendingin $\mathrm{Pb}-\mathrm{Bi}$, stainless steel akan mengalami korosi.

Bahasan termal-hidrolik meliputi proses konduksi, konveksi dan proses aliran pendingin keluar dari teras. Sumber energi pada reaktor berasal dari bahan bakar, energi yang dilepaskan pada reaktor fisi nuklir muncul sebagai energi kinetik dari beberapa jenis hasil reaksi fisi, kemudian energi tersebut diubah menjadi panas dan dipindahkan melalui konduksi termal melintasi elemen bahan bakar, melintasi gap yang memisahkan bahan bakar di cladding dan kemudian melintasi cladding menuju permukaan cladding, dan akhirnya dipindahkan dari permukaan cladding ke pendingin melalui proses konveksi.

Distribusi suhu steady-state di batang silinder dengan sumber panas internal yang diperoleh dari persamaan konduksi panas yang merupakan fungsi temperatur dan jari-jari, dimana diasumsikan bahwa sumber panas dalam bahan bakar adalah seragam, sehingga persamaan konduksi panas untuk keadaan tunak (Waltar dan Reynolds, 1981) adalah,

$$
\vec{\nabla} k \vec{\nabla} T(\bar{r})+q^{\prime \prime \prime}(\bar{r})=0
$$

Untuk keadaan steady-state, persamaan konduksi panas pada pin bahan bakar silinder dengan sumber panas volumetrik, $q$ "', seragam dan dengan mengabaikan panas aksial dimana temperatur bahan bakar sangat tergantung pada konduktivitas termal, $k$ (Duderstadt, 1978), adalah 


$$
\left.\Delta T\right|_{\text {fuel }}=T_{F}-T_{o}=\frac{q^{\prime \prime \prime} \pi r_{F}^{2}}{4 \pi k_{F}}=\frac{q^{\prime}}{4 \pi k_{F}}
$$

Sedangkan untuk mengetahui temperatur bahan pendingin adalah

$$
\left.\Delta T\right|_{\text {cool }}=\left(T_{c l o}-T_{c o}\right)=\frac{q^{\prime \prime}}{h_{s}}=\frac{q^{\prime}}{2 \pi h_{s}\left(r_{F}+t_{C}+t_{G}\right)}
$$

Suatu besaran yang menunjukkan perbedaan tekanan pada kanal pendingin sebelum dan sesudah pendingin melewatinya disebut dengan penurunan tekanan. Tekanan pada saluran dapat hilang atau berkurang disebabkan oleh Faktor friksi (friction factor) dan Faktor bentuk. Keseimbangan tekanan di dalam sistem secara keseluruhan dapat dirumuskan sebagai berikut:

$$
P_{\text {pump }}=P_{d r_{i} \text { core }}+P_{d, h p}-\left[D_{\text {head }, P S G}-P_{d r_{i} P S G}+P_{d_{i}, c p}\right]
$$

Tingkat sirkulasi alamiah dapat diketahui dari grafik perpotongan antara penurunan tekanan dan driving head sebagai fungsi dari laju alir total.

\section{HASIL DAN DISKUSI}

Simulasi rancangan reaktor cepat untuk mengetahui pengaruh ukuran teras terhadap tingkat sirkulasi alamiah bahan pendingin $\mathrm{Pb}-\mathrm{Bi}$ dilakukan optimasi geometri teras berbentuk kubus (square core) dengan empat variasi ukuran teras seperti ditunjukkan pada Tabel 2 .

Tabel 2. Variasi geometri teras square core

\begin{tabular}{|c|c|c|c|c|}
\hline \multirow{2}{*}{$\begin{array}{c}\text { Model } \\
\text { Geometri } \\
\text { Teras }\end{array}$} & \multicolumn{3}{|c|}{ Ukuran Teras } & \multirow{2}{*}{$\begin{array}{c}\text { Volume Teras } \\
\text { (liter) }\end{array}$} \\
\cline { 2 - 4 } & $\mathrm{X}(\mathrm{cm})$ & $\mathrm{Y}(\mathrm{cm})$ & $\mathrm{Z}(\mathrm{cm})$ & 125 \\
\hline M1 & 50 & 50 & 50 & 216 \\
\hline M2 & 60 & 60 & 60 & 343 \\
\hline M3 & 70 & 70 & 70 & 512 \\
\hline M4 & 80 & 80 & 80 & \\
\hline
\end{tabular}

Untuk mendapatkan reaktor dalam keadaan kritis $\left(\mathrm{K}_{\text {eff }} \sim 1\right)$ dapat dicapai dengan melakukan pengaturan pada fraksi pengayaan (enrichment) bahan bakar di tiap bagian teras yang dapat dilihat pada Tabel 3 .

Tabel 3. Fraksi pengayaan (PuN) dan Faktor Multiplikasi efektif pada beberapa model geometri teras square core

\begin{tabular}{|c|c|c|c|c|c|c|}
\hline \multirow{2}{*}{$\begin{array}{c}\text { Geometri } \\
\text { teras }\end{array}$} & \multicolumn{4}{|c|}{ Fraksi pengayaan bahan bakar (PuN) (\%) } & \multirow{2}{*}{ Keff } \\
\cline { 2 - 6 } & $\mathrm{C} 1$ & $\mathrm{C} 2$ & $\mathrm{C} 3$ & $\mathrm{C} 4$ & $\mathrm{C} 5$ & \\
\hline M1 & 19.5 & 19.6 & 19.1 & 13.9 & 16.8 & 1.0000118 \\
\hline M2 & 15.5 & 17.5 & 17.5 & 17.5 & 13.9 & 1.0001712 \\
\hline M3 & 13.7 & 15.4 & 14.8 & 13.9 & 16.8 & 1.0001812 \\
\hline M4 & 12.5 & 14.1 & 13.4 & 13.9 & 16.8 & 1.0001407 \\
\hline
\end{tabular}

Gambar 2 menunjukkan distribusi temperatur pelet bahan bakar sepanjang Z pada kasus laju alir total $4000 \mathrm{~kg} / \mathrm{s}$ dengan daya 150 MWth untuk geometri teras Model M1 hingga 
Model M4. Temperatur meningkat dibagian tengah teras dan menurun dibagian luar. Hal ini disebabkan nilai distribusi daya cukup tinggi pada bagian tengah teras.

Berdasarkan model geometri teras, Gambar 2 distribusi temperatur pada pelet tinggi pada teras berbentuk kubus dengan volume yang lebih kecil, hal ini dikarenakan volume yang kecil mempunyai penampang lintang reaksi fisi yang lebih kecil, sehingga kemungkinan neutron untuk menumbuk bahan fisil semakin besar. Reaksi fisi menghasilkan energi yang dipindahkan dalam bentuk panas.

Berdasarkan besarnya daya termal, Gambar 2.a dengan daya 100 MWth menghasilkan temperatur yang lebih kecil dibandingkan temperatur yang dihasilkan pada daya yang lebih besar. Pada Gambar 2.c untuk model teras M1 yang ukuran terasnya lebih kecil menghasilkan temperatur pelet bahan bakar di titik leleh bahan bakar UN-PuN, sehingga tidak baik untuk digunakan sebagai rancangan reaktor karena dapat mengakibatkan kondisi kecelakaan.

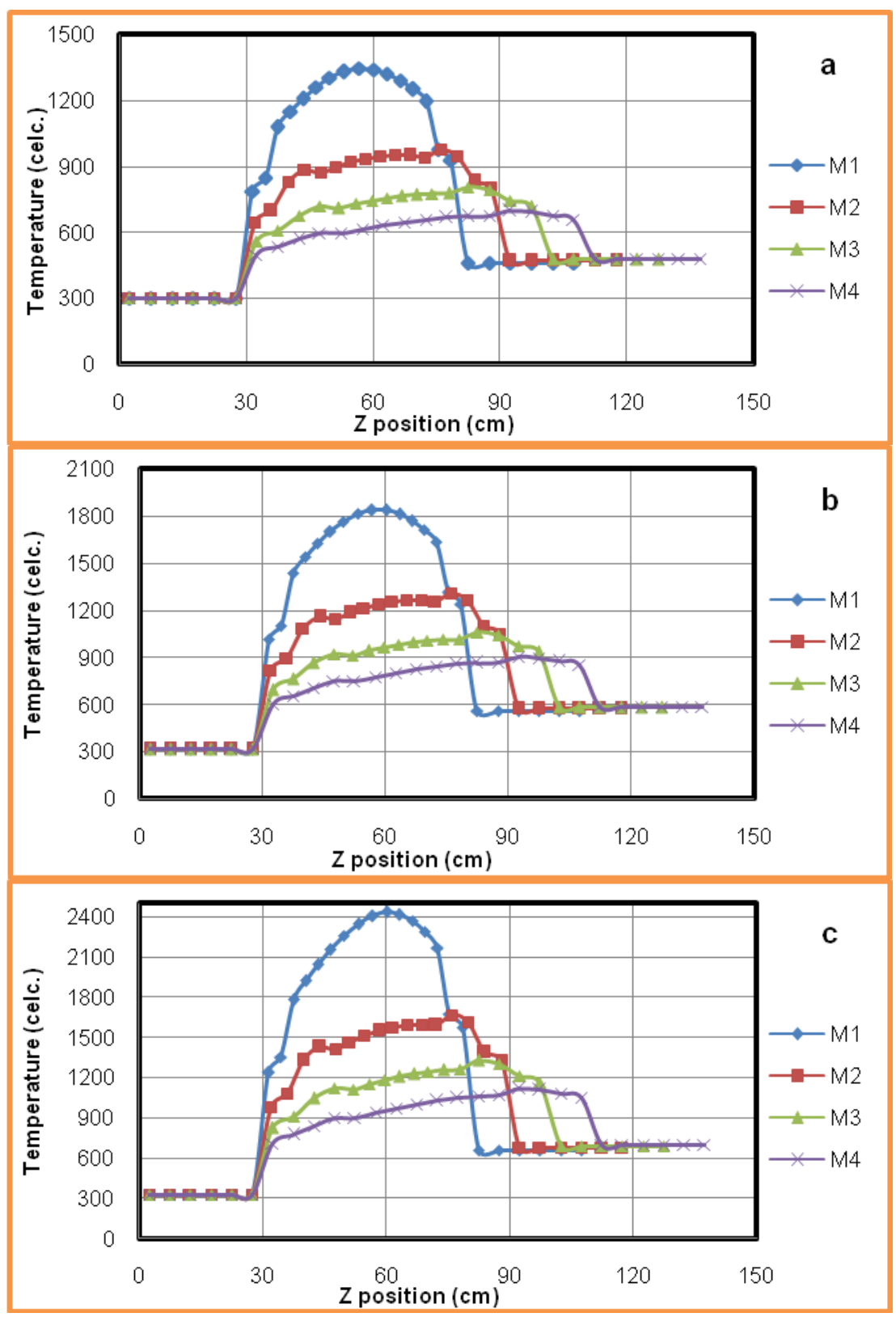

Gambar 2. Distribusi temperatur pelet bahan bakar untuk kasus laju 
alir total $4000 \mathrm{~kg} / \mathrm{s}$ a) $100 \mathrm{MWth}$, b) $150 \mathrm{MWth}$, c) $200 \mathrm{MWth}$

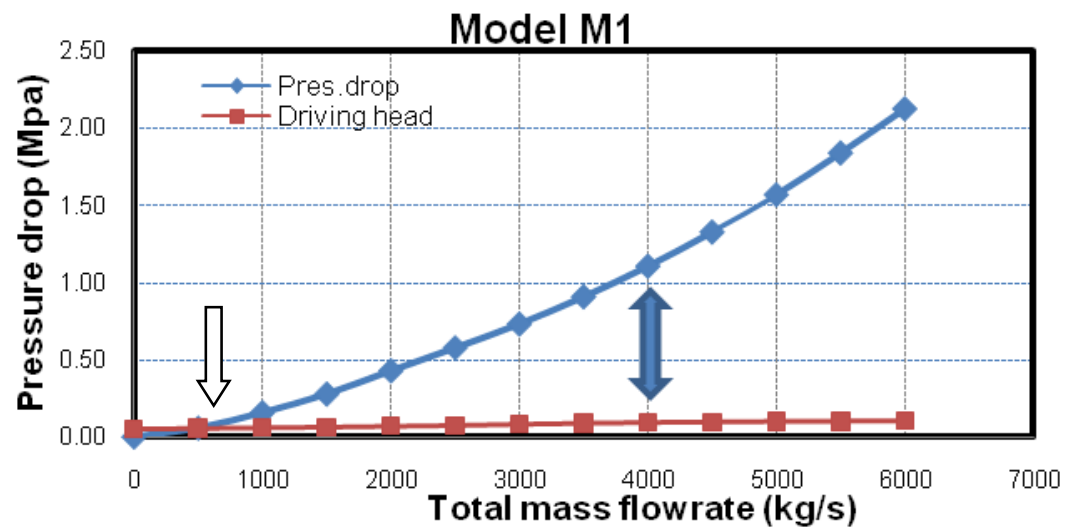

Gambar 3. Perubahan penurunan tekanan dan driving head sebagai fungsi dari laju alir total Model M1 pada daya 150 MWth

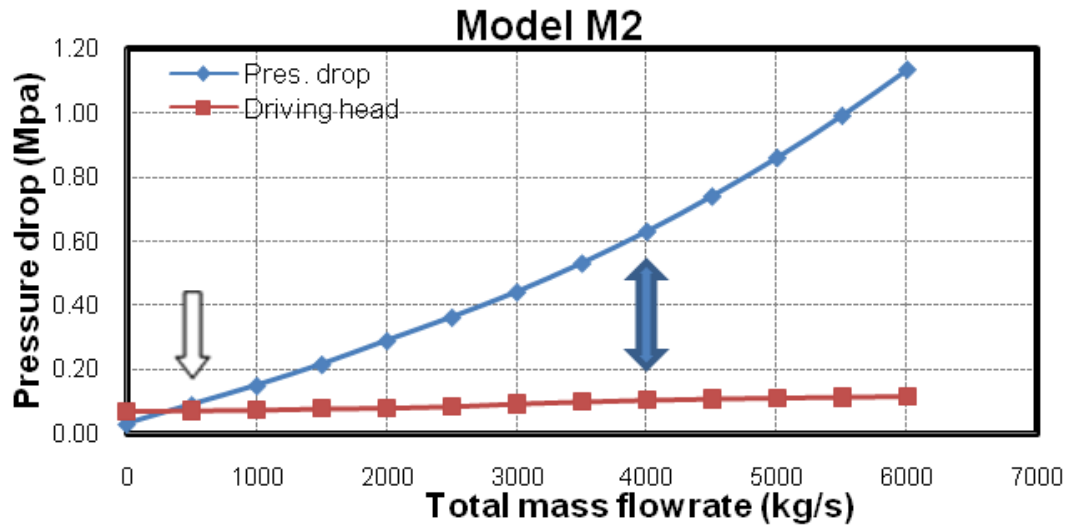

Gambar 4. Perubahan penurunan tekanan dan driving head sebagai fungsi dari laju alir total Model M2 pada daya 150 MWth

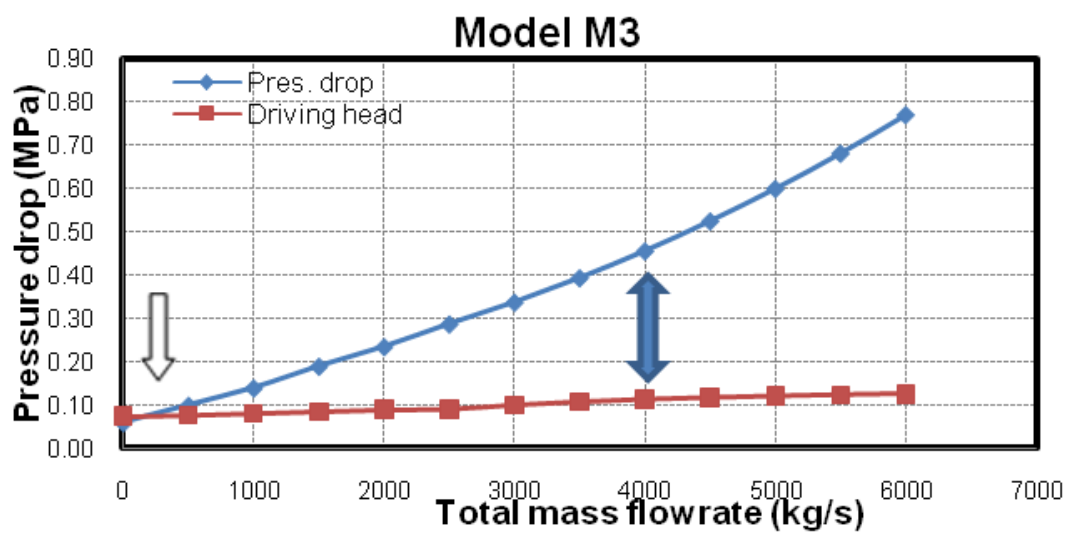

Gambar 5. Perubahan penurunan tekanan dan driving head sebagai fungsi dari laju alir total Model M3 pada daya $150 \mathrm{MWth}$ 


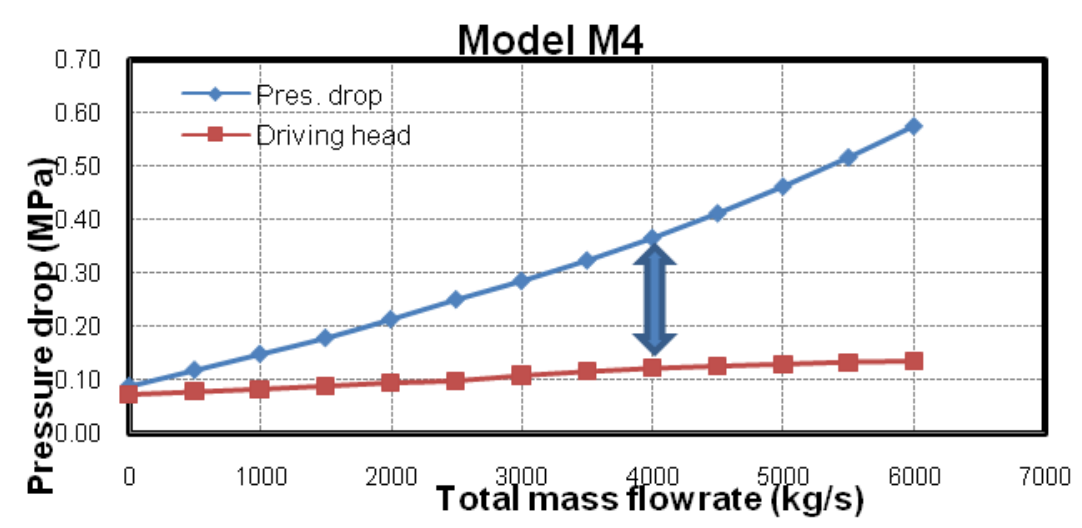

Gambar 6. Perubahan penurunan tekanan dan driving head sebagai fungsi dari laju alir total Model M4 pada daya 150 MWth

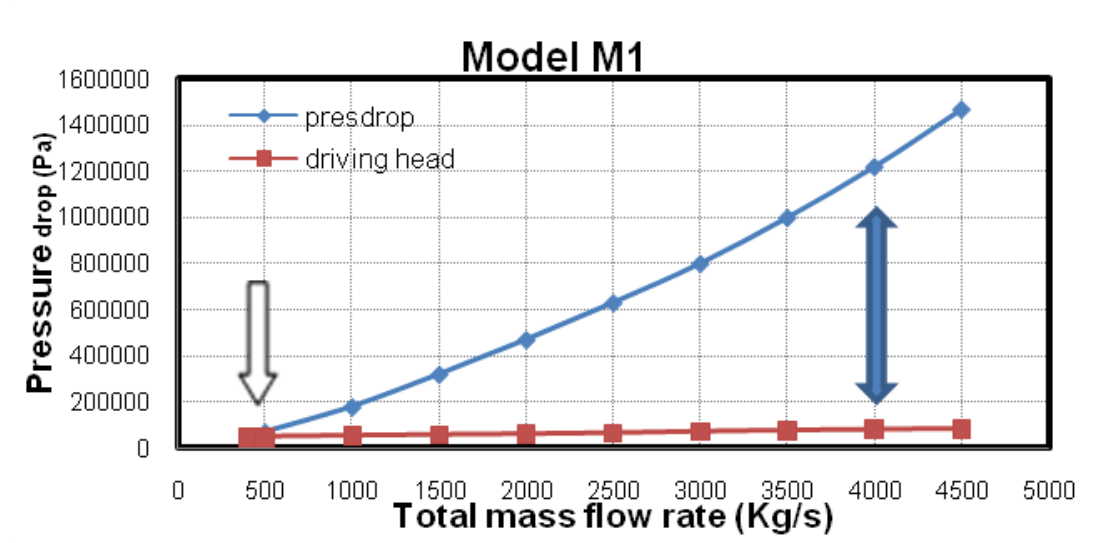

Gambar 7. Perubahan Penurunan tekanan dan driving head sebagai fungsi dari laju alir total Model M1 pada daya 100 MWth

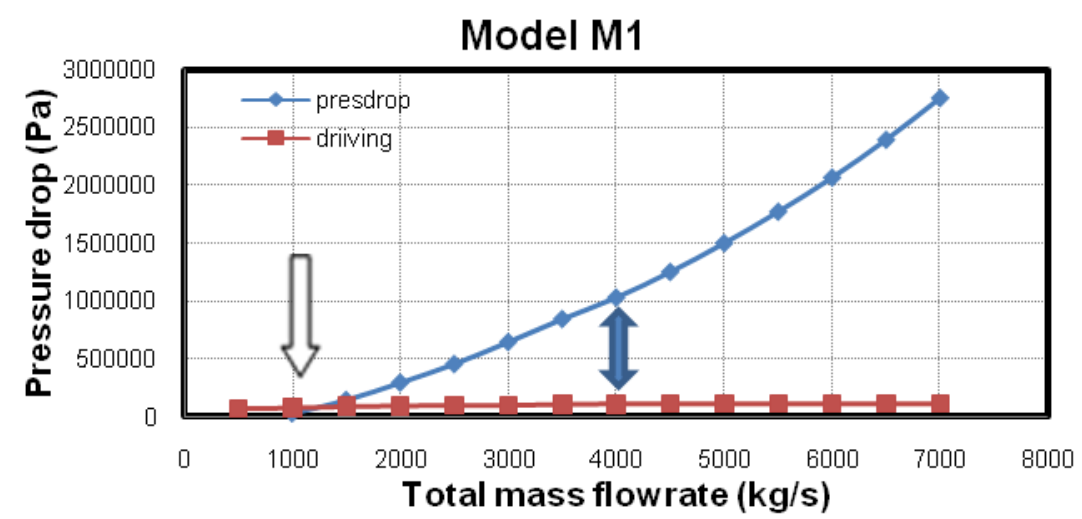

Gambar 8. Perubahan Penurunan tekanan dan driving head sebagai fungsi dari laju alir total Model M1pada daya 200 MWth

Gambar 3 hingga Gambar 6 memperlihatkan perubahan penurunan tekanan dan driving head sebagai fungsi dari laju alir total geometri teras berbentuk kubus pada daya 150 MWth. Dari keempat gambar tersebut terlihat bahwa laju alir total pendingin yang lebih besar membuat penurunan tekanan yang melintasi teras bertambah tinggi. Korelasi ini secara matematis dapat dinyatakan dalam bentuk sebagai berikut, 


$$
\Delta P=f \frac{L}{2 \rho D_{\theta}} \frac{\hat{m}^{2}}{A^{2}}
$$

Model M1 (Gambar 3) memperlihatkan sirkulasi alamiah dicapai lebih cepat daripada Model yang lainnya yang memiliki ukuran teras yang lebih besar. Sirkulasi alamiah akan dicapai pada laju alir total $500 \mathrm{~kg} / \mathrm{s}$ atau $12,5 \%$ dari laju alir total semula sebesar 4000 $\mathrm{kg} / \mathrm{s}$ untuk Model M1. Pada tingkat ini pompa tidak lagi diperlukan, atau dengan kata lain daya pompa sama dengan nol. Sedangkan untuk model dengan ukuran geometri teras yang semakin besar tingkat sirkulasi alamiahnya semakin kecil dan bisa dikatakan (Model M4) tidak tercapai tingkat sirkulasi alamiah, yang berarti dapat menyebabkan terjadinya kecelakaan akibat hilangnya daya pompa primer pada reaktor. Sedangkan untuk model teras yang sama dengan perbedaan daya reaktor memperlihatkan bahwa reaktor dengan daya 100 MWth (Gambar 7), tingkat sirkulasi alamiah terjadi pada laju alir total yang lebih rendah dibandingkan dengan reaktor dengan daya 150 MWth (Gambar 3) dan 200 MWth (Gambar 8). Berarti bahwa reaktor dengan daya yang lebih besar lebih mampu tercapainya tingkat sirkulasi alamiah, akan tetapi pada daya 200 MWth untuk model ukuran teras yang lebih kecil $(\mathrm{M} 1=50 \mathrm{~cm})$ memiliki temperatur pelet bahan bakar yang tinggi dan mencapai temperatur titik lelehnya. Semakin mudah tingkat sirkulasi alamiah dicapai, maka hal ini menunjukkan bahwa margin keselamatan reaktor semakin baik.

Tabel 4. Daya pompa dan tingkat sirkulasi alamiah teras

\begin{tabular}{|c|c|c|c|c|c||}
\hline \hline $\begin{array}{c}\text { Geometri } \\
\text { teras }\end{array}$ & $\begin{array}{c}\text { Daya } \\
\text { Termal } \\
\text { (MWth) }\end{array}$ & $\begin{array}{c}\text { Press-drop } \\
\text { (MPa) }\end{array}$ & $\begin{array}{c}\text { Driving-head } \\
\text { (Mpa) }\end{array}$ & $\begin{array}{c}\text { Daya pompa } \\
\text { (MPa) }\end{array}$ & $\begin{array}{c}\text { Tingkat sirkulasi } \\
\text { alamiah (\%) }\end{array}$ \\
\hline \multirow{4}{*}{ M1 } & 100 & 1,216 & 0,081 & 1,134 & $\sim 10,50$ \\
\cline { 2 - 6 } & 150 & 1,105 & 0,096 & 1,009 & $\sim 12,50$ \\
\cline { 2 - 6 } & 200 & 1,033 & 0,110 & 0,922 & $\sim 25,00$ \\
\hline \hline \multirow{3}{*}{ M2 } & 100 & 0,674 & 0,088 & 0,585 & $\sim 6,25$ \\
\cline { 2 - 6 } & 150 & 0,631 & 0,104 & 0,526 & $\sim 10,00$ \\
\cline { 2 - 6 } & 200 & 0,601 & 0,120 & 0,480 & $\sim 22,50$ \\
\cline { 2 - 6 } & 100 & 0,479 & 0,096 & 0,383 & $\sim 2,50$ \\
\cline { 2 - 6 } & 150 & 0,455 & 0,113 & 0,343 & $\sim 7,50$ \\
\hline \hline \multirow{3}{*}{ M3 } & 200 & 0,439 & 0,130 & 0,308 & $\sim 17,50$ \\
\cline { 2 - 6 } & 100 & 0,380 & 0,103 & 0,276 & $\sim 0,00$ \\
\cline { 2 - 6 } & 150 & 0,367 & 0,122 & 0,245 & $\sim 2,50$ \\
\hline \hline
\end{tabular}

Perbedaan antara penurunan tekanan total dan driving head sistem memberikan perkiraan besarnya daya pompa yang diperlukan. Semakin besar penurunan tekanan maka daya pompa yang diperlukan semakin besar. Daya pompa yang diperlukan saat teras reaktor beroperasi pada laju alir massa total $4000 \mathrm{~kg} / \mathrm{s}$ dan tingkat sirkulasi alamiah untuk model variasi ukuran teras geometri teras berbentuk kubus dan variasi daya diperlihatkan pada Tabel 4. Terlihat bahwa tingkat sirkulasi alamiah semakin besar pada geometri teras berbentuk kubus dengan ukuran teras yang lebih kecil, sedangkan daya pompa yang diperlukan semakin besar pada laju alir massa total semula. 


\section{KESIMPULAN}

Analisis pengaruh ukuran teras terhadap tingkat sirkulasi alamiah bahan pendingin $\mathrm{Pb}-\mathrm{Bi}$ pada reaktor LMFBR menggunakan program DTRIDI FBR memberikan gambaran yang dapat disimpulkan sebagai berikut:

1. Pada model geometri teras berbentuk kubus dengan ukuran teras yang lebih kecil yaitu $\mathrm{x}=\mathrm{y}=\mathrm{z}=50 \mathrm{~cm}$, mencapai tingkat sirkulasi alamiah lebih mudah sebesar $12,5 \%$ dibandingkan dengan ukuran yang lebih besar untuk daya yang sama, yang berarti reaktor mampu bertahan terhadap kondisi kecelakaan ULOF, dengan kata lain margin keselamatan dari reaktor semakin tinggi.

2. Dengan variasi daya untuk ukuran teras yang sama, diperoleh rancangan reaktor dengan daya 200 MWth tingkat sirkulasi alamiah terjadi pada laju alir total yang lebih tinggi dibandingkan dengan reaktor dengan daya $150 \mathrm{MWth}$ dan $100 \mathrm{MWth}$.

\section{DAFTAR PUSTAKA}

1. Agostini, P dan Bertacci, G., (2002), Natural Circulation of Lead-Bismuth in OneDimensional Loop: Experiment and code predictions, Proceedings of 10th International Conference on Nuclear Engineering, Arlington, 14-18.

2. Chang, J-E dan kune Y.S., (2000), Natural Circulation Heat Transfer Analysis for A Liquid Metal Reactor, Proceedings of 8th I International Conference on Nuclear Engineering, Baltimore, MD, USA, 2-6.

3. Duderstadt, J.J. dan Hamilton, L.J., (1978), Nuclear Reactor Analysis, John Wiley \& Sons, Inc., Kanada.

4. Fitriyani, D., (2006), Studi Desain Reaktor daya Nuklir Berbasis Kapal, Disertasi, Departemen Fisika, Institut Teknologi Bandung (ITB).

5. Jaluria, Yogesh, 1980, Natural Convection, Rutgers University, New Jersey.

6. Kazimi, M.S. dan Todreas, N.E., (1993), Thermal Hydraulic Fundamentals, Taylor\&Francis, Amerika.

7. Krane, K.S., (1988), Introductory Nuclear Physics, John Wiley \& Sons Inc., new York.

8. Novitrian dan H.Sofue., (2004), Study on Pb-Bi natural Circulation Phenomena, INES-1, Tokyo-japan, 1-4.

9. Sekimoto, H. dan Makino, S., 2001, LBE-Cooled Long-Life Safe Simple Small Portable Proliferation-Resistant Reactor (LSPR), Bulletin of the Research Laboratory for Nuclear Reactor, Special Issue No.4 ISSN 0387-6144.

10. Takahashi, M., 2004, Conceptual Design And R\&D Of Steam Lift Pump Type LeadBismuth Coolled Boiling Water Small Fast Reactor, COE-INES Newsletter, Vol 1 No.6.

11. Waltar A.E. dan Reynolds, A.B., (1981), Fast Breeder Reactors, Pergamon Press, New York. 